University at Buffalo School of Law

Digital Commons @ University at Buffalo School of Law

1991

\title{
Law, Culture, and Children with Disabilities: Educational Rights and the Construction of Difference
}

David M. Engel

University at Buffalo School of Law

Follow this and additional works at: https://digitalcommons.law.buffalo.edu/journal_articles

Part of the Disability Law Commons, and the Education Law Commons

\section{Recommended Citation}

David M. Engel, Law, Culture, and Children with Disabilities: Educational Rights and the Construction of Difference, 1991 Duke L.J. 166 (1991).

Available at: https://digitalcommons.law.buffalo.edu/journal_articles/492

(c) 1991 Duke Law Journal

C) EDUCATIONAL PERMITTED

This Article is brought to you for free and open access by the Faculty Scholarship at Digital Commons @ University at Buffalo School of Law. It has been accepted for inclusion in Journal Articles by an authorized administrator of Digital Commons @ University at Buffalo School of Law. For more information, please contact lawscholar@buffalo.edu. 


\title{
ESSAY
}

\section{LAW, CULTURE, AND CHILDREN WITH DISABILITIES: EDUCATIONAL RIGHTS AND THE CONSTRUCTION OF DIFFERENCE}

\author{
DAVID M. ENGEL*
}

\section{INTRODUCTION}

The cultural context of law both promotes and subverts efforts at legal change. Profound social and cultural transformations often lead to the creation of new law by legislator or judge. The passage of the Education for All Handicapped Children Act (EHA) ${ }^{1}$ in 1975, for example, resulted from changes in popular conceptions of "handicaps," political activism by and on behalf of persons with disabilities, recognition of the importance of public education to integrate disempowered groups into society, and an increased willingness to perceive persons with disabilities as a minority group to whom the civil rights paradigm should be applied. In this sense, the EHA was a watershed event in a broader process of social and cultural change.

Yet, law can also be altered or even subverted by the social and cultural environment that fostered it. In the case of the EHA, the extraordinary nullifying effect of culture arose not merely from the persistence of stigma, stereotype, and discrimination in the society as a whole, but also from distinctive features of the statute itself. The EHA's ap-

* Professor of Law, State University of New York at Buffalo. A number of colleagues have read and commented on this Essay. I would like to thank Richard L. Abel, Dianne S. Avery, How. ard S. Erlanger, Carol J. Greenhouse, Ronald M. Hager, Joel F. Handler, Alfred S. Konefsky, Craig A. McEwen, Frank W. Munger, and Barbara Yngvesson. I also am indebted to three outstanding research assistants: Wendy Ricks, Margot Watt, and Susan Weber. Above all, I wish to acknowledge and to thank the extraordinary children and families as well as the educators who generously participated in the research on which this Essay is based. This study was funded by the Law and Social Sciences Program of the National Science Foundation (grant SES 87-0330), the American Council of Learned Societies, and the Baldy Center for Law and Social Policy.

1. Education for All Handicapped Children Act, Pub. L. No. 94-142, 89 Stat. 773 (1975) (codified as amended at 20 U.S.C.A. $\$ \S 1400-1485$ (1990)). In 1990, Congress changed the name of the Act to the "Individuals with Disabilities Education Act," Pub. L. No. 101-476, 104 Stat. 1141 (1990). See 20 U.S.C.A. § 1400(a) (1990). 
proach to the protection of the rights of children with "handicapping conditions" made the law's implementation unusually sensitive to local values, perceptions, and practices. Rather than detailing the substantive rights of children with disabilities, the EHA created a novel relationship between their parents and school district personnel and developed a set of procedures to regulate that relationship. Thus, in school districts across the United States, the fate of millions of children with disabilities came to depend upon the peculiar dynamics of interaction between parents and local educators.

The EHA created a "continuing relationship" between parents and educators rather than a particularized set of substantive educational rights. ${ }^{2}$ Continuing relationships have long interested those who study law in its social context. ${ }^{3}$ Generally, researcliers liave assumed that such relationships are guided by informal norms and are resistant to the influence of formal law. Participants are thought to draw upon communitybased understandings and perspectives to guide their behavior in ways that may defy or simply ignore the mandates of official law. ${ }^{4}$

Analysis of the continuing interactions between parents and educators provides an explanation for why the actual consequences of the EHA diverge so markedly from its stated goals. Withm their social and cultural contexts-drawing on available categories, ideas, and valuesparents and educators construct a place for children with disabilities in American society. Cultural conceptions of "liandicap," of public education, of professionahisin, and of power and authority all shape the thoughts and behavior of the central actors within their community settimgs. "Culture," writes Clifford Geertz, "is not a power, something to

2. See J. HANdLer, The Conditions of Discretion: Autonomy, Community, BuREAUCRACY 93 (1980).

3. See, e.g., B. MALINowski, CRIME ANd Custom In SAVAGE Society (1926); see also Macaulay, Non-Contractual Relations in Business: A Preliminary Study, 28 AM. Soc. REV. 55 (1963); Macaulay, An Empirical View of Contract, Law, Private Governance and Continuing Relationships, 1985 Wis. L. Rev. 461, 465 [hereinafter Macaulay, Empirical View].

4. See, e.g., Macaulay, Empirical View, supra note 3, at 468 (noting that relationships and community norms often negate contract duties); Black, Crime as Social Control, in 2 TOWARD A General TheORY of Social Control 1, 13-17 (D. Black ed. 1984); Hawkins, Bargain \& Bluff: Compliance Strategy and Deterrence in the Enforcement of Regulations, 5 LAW \& POL'Y Q. 35, 43 (1983) (noting such a relationship in water pollution control context). In several important respects, the subject of this Essay differs from the usual continuing relations model. First, continuing relationships usually are viewed as systems of private ordering that exist apart from formal law, but in the special education context it was law itself-the EHA-that created the continuing relationship. Second, the continuing relationship between parents and school district personnel is unique because it involves a governmental agency and its clients rather than two private parties linked by affective ties, kinship, or ongoing reciprocal exchanges. Third, the frequency and nature of the interactions within this continuing relationship are founded not on customary practice or mutual agreement but rather on the procedural requirements of the statute. 
which social events, behaviors, institutions, or processes can be causally attributed; it is a context."5

This unique statute, with its unconventional, decentralized system of decisionmaking, requires its chroniclers to go beyond standard analytic legal methods-interpreting legislative history, caselaw, and policy-to engage in studies of the EHA in its social context. Because of the Act's unusual requirement that the beneficiaries of the legislation-children with disabilities and their parents or guardians-participate continuously in its implementation, the Act can best be understood by evaluating how the families and school district personnel, guided by the procedural mandates of the Act, create substantive norms for the education and integration of the children. This analysis deliberately blurs the boundaries between law and culture and emphasizes the inseparability of legal processes from the cultural "contexts" within which they unfold.

Drawing upon fieldwork involving parents, children, and educational officials in western New York, ${ }^{6}$ I examine the EHA in a particular

5. C. GEERTZ, Thick Description: Toward an Interpretive Theory of Culture, in THE INTERPRETATION OF CULTURE: Selected ESSAYS 3 (1973).

6. The fieldwork on which this Essay is based involved children with physical disabilities. In most instances the physical disability resulted from cerebral palsy. Approximately 140 interviews with parents and, in many cases, with the children themselves, took place over a 15-month period (1987-88) in urban, suburban, and rural settings in western New York. Ten families were interviewed frequently throughout this time to explore their changing perceptions, experiences, and conficts and to compare differences in their attitudes and behavior. Twenty other families were interviewed twice to trace the development and implementation of an educational plan for their children over the course of a year. Eight additional families were interviewed only once because their children had just reached school age at the end of the fieldwork period and their contacts with the school districts had just begun. All of the above mentioned interviewees were drawn from the families whose children had graduated over the previous four years from the pre-school program of the United Cerebral Palsy Association of Western New York and who subsequently were involved with the public school systems in their localities. An additional group of 19 families was interviewed after seeking legal assistance on behalf of their physically disabled children from the Education Law Clinic of the Faculty of Law, SUNY at Buffalo. This group, unlike the others, was made up exclusively of those employing legal services.

Thirty further interviews were conducted in 18 school districts throughout western New York with chairpersons and other members of district committees on special education. In a related rescarch project conducted by Susan Weber, every committee member was interviewed in two selected school districts.

Interviews with parents and school district personnel were generally lengthy, wide-ranging, and loosely structured. In nearly all instances, they were tape recorded and later transcribed. Quoted material in this article is taken verbatim from those transcripts, which are on file with the author.

The methodology of this study is interpretive ethnography. Although it was first used in nonwestern "village" studies, researchers have increasingly applied this methodology to socio-legal studies in the United States and other western societies. See, e.g., C. PERIN, EvERYTHING IN ITS Place: Social Order and LaNd Use in America (1977) (study of concepts of social order, status, and land tenure, based on interviews with developers, public officials, and others in the housing field, primarily in Houston and Philadelphia); C. GreEnhousE, Praying for JUSTICE: Faith, ORDER AND COMMUNITY IN AN AMERICAN TOWN (1986) (study of conflict and conceptions of law and religious faith in a suburban community in Georgia, based on interviews with residents); 
social setting and show how law and culture sometimes have combined in unexpected ways. Part II describes the origin and structure of the EHA and the procedural approach by which it attempts to guarantee an "appropriate" public education in the least restrictive environment for children with disabilities. Part III argues that different cultural meanings of "handicap" have shaped both societal perceptions of the children the Act was designed to benefit and of the educational and social potential these children are thought to possess. Part IV examines the struggle to define roles for both professionals and parents in the education of children with disabilities and concludes that the EHA's goal of creating a partnership has clashed repeatedly with community-level norms and expectations. Part V shows how the concept of "rights" itself has been problematic, particularly when asserted by parents against educators on behalf of children with disabilities. The goals of the EHA may have been thwarted, at least in part, because parents are unwilling to jeopardize relationships by asserting their children's rights. To the extent that continuing relationships-with school district officials or with others in the communitybecome desired ends in themselves, the rights and safeguards provided by the EHA may prove meaningless.

\section{The Education for All Handicapped Children ACT}

At least once each year, school district officials throughout the United States invite the parents or guardians of children with disabilities to participate in a process of educational planning with the district's inul-

\footnotetext{
Yngvesson, Making Law at the Doorway: The Clerk, the Court, and the Construction of Community in a New England Town, 22 LAw \& SoC'Y REv. 410 (1988) (study of conflict and conceptions of law and community in a New England town, based on observations of hearings in the court clerk's office and on interviews with the clerk and the disputants); S. MERRY, GETTING JUSTICE AND GETTING Even: Legal Consciousness Among Working-Class AmeriCANS (1990) (study of conflict, legal consciousness, and mediation in Salem and Cambridge, Massachusetts, based on observations and in-depth interviews with community residents).

Interviewees in this study represent a broad range of viewpoints and experiences. All were encouraged to talk at length about their feelings and perceptions, using their own words and categories rather than those of a standardized survey instrument. Because they were interviewed over an extended period of time, most of the parents had the opportunity to describe in great depth their ongoing experiences and consequent changes in their perspectives on issues of disability and education. With time, many parents became familiar with the study and the researcher and were increasingly willing to share their views about issues important to them and their children.

The purpose of this type of research is to use such "texts"-generated by close contact and sustained communication-to interpret the framework of meanings that constitute a "culture" and to discover how meanings are related to human behavior and experience. Interpretive methods based on ethnographic interviews are to be distinguished from survey techniques in which interviewees belong to a probability "sample" that is statistically representative of a larger population about which the researcher attempts to generalize in quantitative terms. Interpretive ethnographies typically do not attempt to predict frequencies in a larger population, although in some instances they have been coupled with research techniques using quantitative data.
} 
tidisciplinary special education team. ${ }^{7}$ This cooperative decisionmaking between local officials and the recipients of governmental services departs radically from the more familiar unilateral administrative models commonly found in the modern welfare state. ${ }^{8}$ The cooperative procedure did not grow out of local traditions or customs. Indeed, it places both parents and educators in highly unfamiliar-and often uncomfortableroles. The choice to involve parents in the decisionmaking process reflects the drafters' behef that the educational opportunities and rights of children with disabihties could best be protected by creating a new arena for controlled interaction between parents and educators. 9 Withm this arena, new rules and guidelines were specified, and procedures for review and appeal were provided. Congress considered this multidisciplinary joint planning conference a key to achieving educational opportunity for children with disabilities. ${ }^{10}$

\section{A. Evolution of Educational Rights for Children with Disabilities: Background of the EHA}

When President Ford signed the EHA ${ }^{11}$ on November 29, 1975, it signalled the culmmation of a long struggle for greater educational opportunity and the beginning of a new era for children with disabilities and their parents. In Brown v. Board of Education, ${ }^{12}$ the United States Supreme Court had defined the opportunity for education as a "right which nuust be made available to all on equal terms." 13 Yet, by the mid1970s this right was demied to millions of children with disabilities who either were receiving inadequate and inappropriate public educations or were excluded entirely from the public school systems. ${ }^{14}$

7. See 20 U.S.C.A. $\S \S 1414(a)(5)$ and 1401(a)(20) (1990); 34 C.F.R. $\S \S 300.340-349$ (1990).

8. See J. HANDLER, supra note 2, at 117-18, 29-32.

9. H.R. CoNF. REP. No. 94-664, 94th Cong., 1st Sess. 43 (1975).

10. The Senate Report on P.L. 94-142 observed, for example, that

the frequent monitoring of a handicapped child's progress throughout the ycar is the most useful tool in designing an educational program for not only the child but those who are responsible for his management in school and at home.... It is the Committee's intent in requiring that individualized planning conferences be provided for each handicapped child that these conferences be utilized as an extension of the procedural protections guaranteed under existing law to parents of handicapped children, and that they be the logical extension and the final step of the evaluation and placement process.

S. ReP. No. 168, 94th Cong., 1st Sess. 11, reprinted in 1975 U.S. Code Cong. \& AdMIN. News $1425,1435$.

11. See supra note 1.

12. 347 U.S. 483 (1954).

13. Id. at 493.

14. See Neal \& Kirp, The Allure of Legalization Reconsidered: The Case of Special Education, LAW \& CONTEMP. ProBs., Winter 1985, at 63. Estimates vary on the number of children affected. Neal and Kirp state that "Two million handicapped children between 7 and 17 years of age were not enrolled in school in 1970." Id. at 67 (citing ChILdReN's Defense Fund, CHILdREN OUT OF 
Public awareness of the phight of children with disabilities increased in part because of advocacy groups such as the National Association for Retarded Citizens (NARC) and the Council for Exceptional Children (CEC). Their lobbying efforts contributed to the creation of a Bureau of Education for the Handicapped within the Office of Education in $1966^{15}$ and led to a series of federal enactments during the late 1960s and early 1970s that both encouraged new state programs and services for children with disabilities and made federal funds available to assist the states in those efforts. ${ }^{16}$ Among the new legislation was Section 504 of the Rehabilitation Act of 1973,17 which provided in general terms that

No otherwise qualified handicapped individual in the United States... shall, solely by reason of his handicap, be excluded from the participation in, be denied the benefits of, or be subjected to discrimination under any program or activity receiving Federal financial assistance. ${ }^{18}$

The regulations later promulgated by the Office for Civil Rights of the Department of Health, Education, and Welfare under Section $504^{19}$ applied the general requirement of nondiscrimination in very particular terms to require free and appropriate public education for children with disabilities. ${ }^{20}$

In addition, two federal court decisions effectively established and defined a constitutional right to public education for children with disa-

ScHool (1974)). Some were excluded by state laws and others were precluded from receiving educational services while confined in custodial institutions. The EHA itself states that more than half of the eight million "handicapped" children in the United States do not receive "appropriate educational services," and that one million are "excluded entirely from the public school system." 20 U.S.C.A. § 1400(b)(1), (3)-(4) (1990).

15. Elementary and Secondary Amendments of 1966, Pub. L. No. 89-750, §609, 80 Stat. 1191, 1208. For an account of the events leading up to the 1966 Amendments, see E. LeviNE \& E. WEXLER, PL 94-142: AN ACT OF CONGRESS 27-33 (1981).

16. See, e.g., Elementary and Secondary Amendments of 1966, Pub. L. No. 89-750, 80 Stat. $1191,1204-08$ (1966) (establishing a Bureau of Training and Education for Handicapped Students in the Office of Education and authorizing grants to assist states in expanding and improving education programs for "handicapped" students); Elementary, Secondary, and other Educational Amendments of 1969, Pub. L. No. 91-230, 84 Stat. 121, 175-88 (1970) (establishing the National Advisory Committee on Handicapped Children; reauthorizing grants to assist states in expanding and improving education programs for "handicapped" students); Education Amendments of 1974, Pub. L. No. 93-380, 88 Stat. 484, 579-85 (1974) (extending the Advisory Committee until 1977; reauthorizing grants to assist states in expanding and improving education programs for "handicapped" students). This federal legislation is usefully summarized in W. Newhouse, Law and Public Education in New York State 11-45 (1988) (unpublished manuscript on file with author).

17. Pub. L. No. 93-112, 87 Stat. 394 (codified as amended at 29 U.S.C.A. $\$ 794$ (1990)).

18. Id. The evolution of Section 504 and the EHA is summarized in L. RothSTEIN, SPEclaL EDUCATION LAW 11-12 (1990).

19. 34 C.F.R. $\S 104$ (1990).

20. These regulations were drafted in coordination with the Bureau of Education for the Handicapped, which was concurrently drafting regulations under the EHA, discussed below. See E. LEVINE \& E. WEXLER, supra note 15, at 111. 
bilities: Pennsylvania Association for Retarded Children (PARC) v. Pennsylvania ${ }^{21}$ and Mills v. Board of Education. ${ }^{22} P A R C$ involved a class action suit to prevent the state of Pennsylvania from applying statutes that precluded "mentally retarded" children from receiving public education. ${ }^{23}$ The litigation concluded with a consent decree that enjoined the defendants from applying the statutes and required them

to provide, as soon as possible but in no event later than September 1, 1972 , to every retarded person between the ages of six and twenty-one years as of the date of this Order and thereafter, access to a free public program of education and training appropriate to his learning capacities. . . . ${ }^{24}$

The court held that the plaintiffs had "established a colorable constitutional claim,"2s and that the state had violated plaintiffs' fourteenth amendment equal protection rights by providing public education to other children while denying "mentally retarded" children a similar opportunity. ${ }^{26}$ The $P A R C$ decision also contained an "Amended Stipulation," which detailed the due process protections guaranteed to "mentally retarded" children and their parents during the processes of educational classification, programming, and placement. ${ }^{27}$ As in the approach later adopted by the drafters of the EHA, the court linked the constitutional right (equal educational opportunity) to elaborate guarantees of notice, due process hearings, and legal representation.

Mills, also decided in 1972, involved a broader range of disabilities than did $P A R C$. The Mills plaintiffs included persons labeled "mentally retarded" (as in $P A R C$ ), as well as individuals who were said to have behavioral, emotional, or lyyperactivity disorders. ${ }^{28}$ All had been excluded from public schools because of their disabilities, and none had been provided with alternative public educations. The Mills court, like the $P A R C$ court, found that the exclusion violated the plaintiffs' constitutional rights. ${ }^{29}$ The court granted a motion for summary judgment and required the District of Columbia to provide a "free and suitable" public education for each school age child "regardless of the degree of the child's mental, physical or emotional disability or impairment."30

21. 343 F. Supp. 279 (E.D. Pa. 1972).

22. 348 F. Supp. 866 (D.D.C. 1972).

23. PARC, 343 F. Supp. at $281-82$.

24. Id. at 302 .

25. Id. at 288 n. 19 .

26. Id. at 297.

27. Id. at 303-06.

28. Mills v. Board of Educ., 348 F. Supp. 866,868 (D.D.C. 1972).

29. Id. at $874-75$.

30. Id. at 878. The Mills decision was also significant for asserting that school districts could not justify unequal treatment of children with disabilities on financial grounds. If funds are insuffi- 
$P A R C$ and Mills became potent symbols of the constitutional claims of children with disabilities to a public education. The Senate Report of the EHA asserted, perhaps with some exaggeration, that $P A R C$ and Mills "guarantee the right to free publicly-supported education for handicapped children and have resulted in similar court actions in the State and Federal courts throughout our nation." 31 Of equal importance was the linkage that these two cases established between the goal of equahty of educational opportunity and the assumption that procedural safeguards provide the best means of translating the legal rights of children into meaningful educational placements and programs.

\section{B. Educational Rights Under the EHA}

The EHA adopted a similar procedural approach three years later. In broad terms, Congress designed the Act to assure that:

all handicapped children ${ }^{32}$ have available to them ... a free appropriate public education which emphasizes special education and related services designed to meet their unique needs, to assure that the rights of handicapped children and their parents or guardians are protected, to assist States and localities to provide for the education of all handicapped children, and to assess and assure the effectiveness of efforts to educate handicapped children. ${ }^{33}$

The significant substantive rights guaranteed by the EHA were, however, delineated far less carefully than the procedural steps by which they were to be protected. Central to the EHA was the requirement that all "hand-

cient, then the burden should not fall disproportionately on those who are considered "handicapped":

If sufficient funds are not available to finance all of the services and programs that are needed and desirable in the system then the available funds must be expended equitably in such a manner that no child is entirely excluded from a publicly supported education consistent with his needs and ability to benefit therefrom. The inadequacies of the District of Columbia Public School System whether occasioned by insufficient funding or administrative inefficiency, certainly cannot be permitted to bear more heavily on the "exceptional" or handicapped child than on the normal child.

Id. at 876.

31. S. REP. No. 168, 94th Cong., Ist Sess. 6, reprinted in 1975 U.S. CODE CONG. \& ADM1N. News 1425, 1430. See generally W. Newhouse, supra note 16, at 86-97 (suggesting that Congress overstated the constitutional implications of $P A R C$ and Mills).

32. The term "children with disabilities" replaced the term "handicapped children" in this section and throughout the statute under the 1990 amendments. See supra note 1.

33. 20 U.S.C. $\$ 1400$ (c) (1988). The EHA was a spending bill, and states seeking to obtain EHA funds had to comply with its provisions concerning the administration of special education in each locality. In theory, a state could decide to evade the requirements of the EHA by declining the federal funds it provides. After all, the federal monies constitute only a small portion of the funding for public education in each school district. However, every state has now agreed to participate in the EHA system. It appears that many of the EHA requirements are regarded by state officials as rights that could be asserted as constitutional claims or claims under Section 504 even in the absence of the EHA. See W. Newhouse, supra note 16, at 11-79 and L. RothSTE1N, supra note 18, at 12. 
icapped children" 34 receive a "free appropriate public education" 35 in the least restrictive environment for each child. ${ }^{36}$ Both concepts- "free and appropriate" and "least restrictive environment"-remained ill-defined and problematic.

A "free and appropriate education" was defined as one that involved special education programmmg with support from related services, in conformity with an individualized prograin tailored specifically for the needs of each child. ${ }^{37}$ Some observers interpreted the "appropriate" requirement to mean that each "handicapped" child must receive an education designed to maximize his or her potential ${ }^{38}$ or to provide an opportunity to achieve full potential comınensurate to the opportunity provided "non-handicapped" children. ${ }^{39}$ The United States Supreme Court rejected these niterpretations of the EHA's "appropriate" requirenient in Board of Education v. Rowley. ${ }^{40}$ The majority opinion of thenJustice Rehnquist held that "free appropriate public education" required only that a school district provide "access to specialized instruction and related services which are individually designed to provide educational benefit to the handicapped child." 41 Thus, even if the benefit is less than that received by non-"handicapped" children or could be enhanced or even maximized by additional support, some benefit nonetheless satisfies the requirement. Significantly, the Rowley Court suggested that the true import of the EHA lay inore in its procedural protections than in an articulation of soine elusive substantive standard of educational quality. ${ }^{42}$

Interpretation of the term "appropriate education" was not the only source of debate. Similar uncertanity arose concerning the requirement that the education of "handicapped" children be provided in the "least

34. The term "handicapped children" was defined broadly to include those who were "mentally retarded, hard of hearing, deaf, speech or language impaired, visually handicapped, seriously emotionally disturbed, orthopedically impaired, or other health impaired children, or children with specific learning disabilities, who by reason thereof require special education and related services." 20 U.S.C. $\S 1401(a)(1)$ (1988). The 1990 amendments of the EHA changed the terminology of this section and expanded it to include children with autism and traumatic brain injuries. 20 U.S.C.A. $\S 1401(a)(1)(A)(1990)$. For a discussion of "special education" and "related services," see infra text accompanying notes $45-46$.

35. 20 U.S.C.A. $\S 1400$ (c) (1990).

36. 34 C.F.R. $\$ \S 300.550-.556$ (1990). See also 20 U.S.C.A. $\$ 1412(5)(B)$ (1990) (requiring that children with disabilities be "educated with children who are not disabled" to the "maximum extent appropriate").

37. 20 U.S.C.A. $§ 1401(a)(18)(1990)$.

38. See H.R. REP. No. 332, 94th Cong., 1st Sess. 19 (1975). See also Board of Educ. v. Rowley, 458 U.S. 176, 214 (1982) (White, J., dissenting) (citing 121 CoNG. REc. 23709 (1975)).

39. This was the holding of the district court in Rowley v. Board of Educ., 483 F. Supp. 528, 534 (1980).

40. 458 U.S. 176 (1982).

41. Id. at 201.

42. Id. at 193-95. 
restrictive environment" appropriate for each child..$^{43}$ The statutory goal was to prevent systematic exclusion of children with disabilities from mainstream schools and classrooms and to integrate these children with nondisabled children "to the maximum extent appropriate." 44 The goal of integration was to be facilitated by providing "handicapped" students with "special education" programming and with "related services." The statute defined "special education" as

specially designed instruction, at no cost to parents or guardians, to meet the unique needs of a handicapped child, including classroom instruction, instruction in physical education, home imstruction, and instruction in hospitals and institutions. ${ }^{45}$

"Special education" thus entailed individualized programming of instruction for children with disabilities, but such programming alone did not guarantee the integration of "handicapped" children "to the maximum extent appropriate." Legislators recognized that academic progress for children with special needs was unlikely unless the schools also provided educational support in the form of "related services," sucl1 as speech therapy, physical and occupational therapy, and psychological counseling. ${ }^{46}$

43. See 20 U.S.C.A. $\$ 1412$ (1990) (substituting the term "children with disabilities" for "handicapped children"). According to section 1412,

In order to qualify for assistance under this subchapter in any fiscal year, a State shall demonstrate to the Secretary that the following conditions are met:

(5) The State has established ... (B) procedures to assure that, to the maximum extent appropriate, children with disabilities, including children in public or private institutions or other care facilities, are educated with children who are not disabled, and that special classes, separate schooling, or other removal of children with disabilities from the regular educational environment occurs only when the nature or severity of the disability is such that education in regular classes with the use of supplementary aids and services cannot be achieved satisfactorily.

Id. § 1412(5)(B). See also id § 1414(a)(1)(C)(iv); 34 C.F.R. § 300.550(b)(1) (1990).

44. 20 U.S.C.A. § 1412(5)(B) (1990); see also 34 C.F.R. \$300.550(b) (1990) ("Each public agency shall insure: (1) That to the maximum extent appropriate, handicapped children, including children in public or private institutions or other care facilities, are educated with children who are not handicapped.").

45. 20 U.S.C. $\$ 1401$ (a)(16) (1988). The definition of "special education" in the 1990 amendments is similar:

The term "special education" means specially designed instruction, at no cost to parents or guardians, to meet the unique needs of a child with a disability, including (A) instruction conducted in the classroom, in the home, in hospitals and institutions, and in other settings; and (B) instruction in physical education.

Id.

46. See 20 U.S.C.A. §1401(a)(17) (1990). "Related Services" are defined as

transportation, and such developmental, corrective, and other supportive services (including speech pathology and audiology, psychological services, physical and occupational therapy, recreation, including therapeutic recreation and social work services, and medical and counseling services, including rehabilitation counseling, except that such medical services shall be for diagnostic and evaluation purposes only) as may be required to assist a child with a disability to benefit from special education, and includes the early identification and assessment of disabling conditions in children. 
Critics maintain that, despite the rather general mandate of education in the "least restrictive environment," the passage of the EHA has not led to greater integration of children with disabilities: "[T]he extent of mainstreaming still is heavily dependent on attitudes of the staff and administrators. Indeed, available data and qualitative judgments indicate little overall impact on the extent to which handicapped children are mainstreamed." 47 Although far more children receive services now than before the passage of the EHA, ${ }^{48}$ professional practices and incentives tend to emphasize pull-outs, self-contained classes, or completely segregated institutional settings rather than the delivery of programs and services to children placed in integrated classrooms. ${ }^{49}$ The emphasis on segregated programming particularly troubles critics who contend that this "special" approach is actually less beneficial to students with disabilities than regular classroom placements. ${ }^{50}$ Furthermore, social attitudes towards children with disabilities are unlikely to change so long as these children have little or no contact with their non-disabled classmates.

In short, although the general purpose of the EHA was to provide children with disabilities an "appropriate" education in the "least restrictive environment," both these goals remain vague in theory as well as in practice, with few guidelines to shape the substantive content of these newly articulated rights. There are several reasons why the congressional approach was short on substance and long on procedures. First, states and localities were concerned that the federal government might attempt to usurp control over educational standards by formulating specific substantive rights for children with disabilities. ${ }^{51}$ A statutory approach that emphasized process would leave substantive standards in their traditional domain-the states and the individual school districts. Second, the variety of disabilities and needs made it difficult to formulate universally applicable substantive standards:

47. Clune \& Van Pelt, A Political Method of Evaluating the Education for All Handicapped Children Act of 1975 and the Several Gaps of Gap Analysis, LAW \& CONTEMP. ProBs., Winter 1985, at 20.

48. See Gartner \& Lipsky, Beyond Special Education: Toward a Quality System for All Students, 57 HARV. EDUC. REv. 367, 371 (1987) $(650,000$ more children with disabilities received services in the 1985-86 school year than in 1975, the year the EHA was enacted).

49. Gartner and Lipsky state that $74 \%$ of all special education students in the United States are in pull-out or separate programs. Id. at 374.

50. See id. at 375-76. Integration is, of course, a two-way street. The greater the segregation of children with disabilities, the less benefit non-disabled children receive from exposure to their "handicapped" peers.

51. See Note, Enforcing the Right to an "Appropriate" Education: The Education for All Handicapped Children Act of 1975, 92 HARv. L. Rev. 1103, 1109 (1979); see also Neal \& Kirp, supra note 14, at 71; E. LEVINE \& E. WEXLER, supra note 15, at 90-91. 
A deaf child has special needs quite unlike those of a mentally retarded child. Even the single label "mentally retarded" encompasses a broad spectrum of widely divergent needs. A system of regulations that prescribed a specific program for each type of handicap would inevitably ignore important differences among individuals. ${ }^{52}$

Finally, the drafters believed that detailed procedural-rather than substantive-standards would provide better protection for parents and children who might seek to challenge local school officials under the new law. One congressional staff member said "[y]ou have to go for procedural safeguards rather than substantive things; they're too hard to deal with in litigation. The judges can deal with procedures."53

Thus, the EHA drafters chose to rely on procedural safeguards or rights as a means to achieve the broader substantive goal that "handicapped" children would receive an "appropriate" education im integrated settings. This choice affects the operation of the EHA within each school district and shapes the interactions between parents and educators. Before discussing these imteractions, it is therefore necessary to examine the procedural requirements of the EHA.

\section{EHA Procedures and Parental Participation}

The EHA envisions that individually tailored programs for students with disabilities will emerge not from the application of predetermined standards or criteria, but from the give-and-take of a multidisciplinary committee in each school district. The statute requires that these meetings include a specialist in special education, the child's teacher, the child's parents or guardian, and the child "whenever appropriate."54 In New York State, the primary research site for this study, the multidisciplinary committees are called Committees on Special Education (CSE). Committee members are appointed by the board of education or trustees in each school district, and New York law additionally requires that each CSE include "a school psychologist, a teacher or administrator of special education, a school physician, [and] a parent of a handicapped child residing in the school district ...."55

52. Note, supra note 51 , at 1108 .

53. D. Neal \& D. Kirf, The Allure of Legalization Reconsidered: The Case of SPECIAL. EdUCATION 22 (1983) (Stanford University Institute for Research on Educational Finance and Governance Project Report No. 82-A27) (earlier draft of Neal \& Kirp, supra note 14). The congressional staff member's assertion is debatable, particularly because the vast majority of parents do not consider raising legal challenges. These parents might participate more effectively in the joint decisionmaking process, however, if they had a clearer conception of the substantive standards of their child's program.

54. 20 U.S.C.A. $\S 1401(a)(20)$ (1990); 34 C.F.R. $§ 300.344(a)$ (1990).

55. N.Y. Educ. LAW $\S 4402(1)(b)(1)$ (McKinney 1990). For convenience I shall refer to the multidisciplinary teams by their New York designation: CSE. 
The CSE must develop an IEP (individualized educational program) for each classified student and must meet at least once a year to review and, if necessary, revise it. ${ }^{56}$ According to the terms of the EHA, the IEP inust include:

(A) a statement of the present levels of educational performance of such child, (B) a statement of annual goals, including short-term instructional objectives, $(C)$ a statement of the specific educational services to be provided to such child, and the extent to which such child will be able to participate in regular educational programs, ... (E) the projected date for initiation and anticipated duration of such services, and $(F)$ appropriate objective criteria and evaluation procedures and schedules for determiming, on at least an annual basis, whether instructional objectives are being achieved. ${ }^{57}$

The IEP is the child's ticket to an "appropriate" education. It requires that the school district assess the child's individual needs and determine how those needs can be met in every phase of his or her education, including transportation, academic instruction, physical education, and extracurricular activities. The IEP serves several purposes. In the words of one policymaker: "We intended to strengthen the hands of parents. ... It was a way of individualizing and contractualizing the relationships and involving parents in the process. ... It's a way of enforcing what should be delivered to kids. While it's said not to be a contract, it is a contract for service." 58

For each child classified under the EHA, the IEP provides a substantive definition of an "appropriate education" with a specificity that the EHA lacks. In the formulation of the IEP, moveover, the parents have numerous procedural safeguards to ensure their satisfaction with its contents. The EHA grants parents a right to attend the IEP conference, ${ }^{59}$ and the regulations require notice and mutual agreement as to the time and place of the conference. 60 The parents are permitted to invite anyone-including an advocate-to accompany them to the conference. ${ }^{61}$ In addition, they have the right to examine their child's records, ${ }^{62}$ to request an independent evaluation in cases in which they question the school district's evaluation, ${ }^{63}$ to receive notice of proposals

56. 20 U.S.C.A. $\S \S 1414(\mathrm{a})(5)$ and 1401(a)(20) (1990); 34 C.F.R. $\S 300.342$ (1990).

57. 20 U.S.C.A. $\S 1401(\mathrm{a})(20)(1990)$.

58. The anonymous policymaker is quoted in Neal \& Kirp, supra note 14, at 72 n.39.

59. 20 U.S.C.A. § 1401(a)(20) (1990).

60. 34 C.F.R. $\S 300.345$ (a) (1990).

61. Id. $\S 300.344(\mathrm{a})(5)$.

62. 20 U.S.C.A. $\S 1415($ b)(1)(A) (1990); 34 C.F.R. $\$ 300.502$ (1990).

63. 20 U.S.C.A. $\$ 1415(\mathrm{~b})(1)(A)(1990) ; 34$ C.F.R. $\S 300.503$ (1990). 
to change their child's classification or program, ${ }^{64}$ and to grant or withhold consent to preplacement evaluations and initial placements. ${ }^{65}$

Of special significance is the parents' right to initiate an inpartial due process hearing when they disagree with the school district's decision as to "the identification, evaluation, or educational placement of the child or to the provision of a free appropriate public education to the child."66 Parents in New York are accorded a two-tier impartial hearing process; they can appeal the ruling of a district-level hearing to the State Commissioner of Education. ${ }^{67}$ In all states, an aggrieved party dissatisfied with a final decision in the appeal process can initiate a civil action in a state or federal district court. ${ }^{68}$ In addition, parents may bring a federal civil rights action under other statutes, such as Section 504 of Title V of the Rehabilitation Act of $1973,{ }^{69}$ if the parents believe that the school district has violated these more generalized antidiscrimination standards. ${ }^{70}$

The highly specific and detailed procedural provisions of federal and state statutes and regulations contrast dramatically with the more generalized, even ambiguous, substantive provisions. In effect, this is what parents are told by federal and state autliorities, "We cannot say exactly what sort of education your child is entitled to, but we can ensure your right to have a say and to challenge important decisions of the CSE through an elaborate review process."

This approach places great emphasis on the IEP conference and on the parents' ability to understand and participate effectively in the workings of the CSE. In Rowley v. Board of Education, Justice Rehnquist stated with confidence that "parents and guardians will not lack ardor in seeking to ensure that handicapped children receive all of the benefits to which they are entitled by the Act."71 Effective parental participation in the IEP conference, however, proved to be the exception rather than the rule for families in this study. Furthermore, since they usually did not know the extent of their children's substantive educational rights-and

64. 20 U.S.C.A. $\S 1415(b)(1)(C)$ (1990); 34 C.F.R. $\S 300.504$ (a) (1990).

65. 34 C.F.R. $\S 300.504(b)(1990)$.

66. Id. $\S 300.506$; see also id. $\S 300.504$ (a). An allowance for impartial due process hearings is also specified in 20 U.S.C.A. $\$ 1415$ (b)(2) (1990).

67. 20 U.S.C.A. § 1415(c) (1990); 34 C.F.R. § 300.510 (1990); N.Y. EDuc. LAW § 4404(2) (McKinney 1990). The EHA leaves it to the states to choose between a two-tier impartial hearing process like New York's and a one-tier process in which every hearing would be conducted at the state level. See 20 U.S.C.A. $§ 1415(b)(2)$ (1990).

68. See 20 U.S.C.A. $\S 1415($ e) (1990); 34 C.F.R. $\S 300.511$ (1990).

69. 29 U.S.C. $\$ 794$ (1988).

70. The relationship between the EHA and other federal civil rights statutes (including Section 504 ) is discussed in L. RothSTE1N, supra note 18, at 27-31.

71. 458 U.S. 176, 209 (1982) (footnote omitted). 
we liave seen that the EHA provides little guidance in this respect-they rarely lodged formal appeals alleging a rights violation. ${ }^{72}$

In the following Parts of this Essay, I examine the interactions between parents and Committees on Special Education, witl a particular focus on the perceptions and beliavior of the parents. I ask how the parents interact witl the CSE to flesh out the substantive definition of an "appropriate" education, which the federal and state statutes left vague. Because very few parents appeal local decisions or engage in litigation with their school districts, the substantive outcoines of the IEP conferences essentially constitute the "law of special education" in eacli district. Through their interactions, guided as much by culture as by law, parents and educators in each district create a "living law"73 that has a powerful and direct mipact on local understandings of the status of persons with disabilities im American society.

\section{The Cultural Meanings of "Handicap"}

The EHA was founded upon the concept of "liandicap," and the rights, opportunities, and protections of the Act were inade available only to cliildren who came witlin the definition of this term. Yet the concept of "liandicap," even as it appeared in the EHA, ${ }^{74}$ is embedded in layers of meaning and symbols through which our culture has responded to the problem of difference or "otlerness." Cultural values and perceptions concerning "liandicaps" affect all participants in the CSE process by defining their expectations about the clild and their assumptions about the role each should play in the decisionmaking process. In this Part, I discuss low the meanings of this concept to parents and school officials influence the miplementation of the EHA.

\section{A. "Handicap" as a Cultural Construct}

In a particularly noving passage in his book, The Man Who Mistook His Wife for a Hat, ${ }^{75}$ Oliver Sacks, a neurologist and specialist in brain

72. None of the 38 families selected from the list of UCPA pre-school graduates had ever participated in an impartial hearing. The extreme infrequency of rights invocation in this group of interviewees made it necessary to seek an additional set of interviews with the atypical lawyer-users who had availed themselves of the services of the Education Law Clinic. See description of interviews, supra note 6.

73. E. Ehrlich, Fundamental Principles of the Sociology of LAw 486-506 (1936).

74. 20 U.S.C. $\S 1401$ (a)(1) (1988). The term "handicap" has now been replaced by "disability" in the statute. See supra note 32 . I include the concept of "handicap" in this discussion of disability and difference, however, because it is still used in everyday speech, because it remained central to the EHA until October 1990, and because it was a key factor in the interactions between the parents and educators that I studied in 1987-88.

75. O. SACks, The Man Who Mistook His Wife for a Hat (1987). 
dysfunction, recounts his fortuitous ghmpse of a patient named Rebecca following an initial examination in the hospital. During the examination, he perceived her "as a casualty, a broken creature, whose neurological impairments I could pick out and dissect with precision." 76 But in the hospital garden, he observed a very different person, a composed, integrated, and responsive human being who reacted naturally and poetically to the beauty around her:

She had done appallingly in the testing-which, in a sense, was designed, like all neurological and psychological testing, not inerely to uncover, to bring out defects, but to deconpose her into functions and deficits. She had coine apart, horribly, in formal testing, but now she was mysteriously "together" and composed.

Why was she so decomposed before, how could she be so recoinposed now? $?^{77}$

Sacks concludes that the fornal testing evaluated her problem-solving abilities but ignored her imaginative and integrative capacities. The standard tests, which she had failed so miserably, were designed only to identify deficits:

[T] he tests had given no inkling of anything but the deficits, of anything, so to speak, beyond her deficits. They had given me no hint of her positive powers, her ability to perceive the rcal world-the world of nature, and perhaps of the imagination-as a coherent, intelligible, poetic whole: her abihty to see this, think this, and (when she could) live this; they had given me no intimation of her inner world, which clearly was coinposed and coherent, [when] approached as something other than a set of probleins or tasks. ${ }^{78}$

Sacks thus criticizes the traditional diagnostic emphasis on deficits rather than "powers." During my fieldwork, a spokesperson for children with disabilities, echoing Sacks' frustration, commented that she always tries to steer CSE discussions away from a preoccupation with deficits and attempts to ask mstead, "What are this child's strengths, and how can we build on them?"79 The question sounds unexceptionable, yet it is foreign to the mode of thought that dominates most meetings.

The "science of defectology" pervades the culture that surrounds special education. The einphasis on deficits in CSE meetings has important implications for the parental participation considered essential to the successful operation of the EHA. The "scientific" aspects of defectology

76. Id. at 180 .

77. Id. at $180-81$.

78. Id. at 181. The bracketed word "when" is used here to correct an apparent typographical error in the original text.

79. Interview with "Karen Hull," parent activist and CSE member (August 9, 1988). Because of the sensitive and personal nature of these interviews, all participants were promised anonymity. Names used in this Essay are pseudonyms. 
are expressed in an esoteric language that parents generally cannot "speak." More importantly, an emphasis on deficits tends, in Sack's terms, to banish from consideration the "composed and coherent" children whom the parents perceive. ${ }^{80}$ They are replaced at the IEP conference by "broken creatures," by bundles of defects, who bear only slight resemblance to the children as the parents know them.

A cultural construct, the "science of defectology"81 is one of many possible ways to understand children with disabilities. This "science" has gained great force and prestige witl the rise of professionalism, particularly in the field of special education. One must recognize and examine the various cultural constructs, botli popular and professional, that sliape perceptions of children with disabilities, for they affect parental power and participation througliout the CSE process. We employ these cultural images and symbols unthinkingly and assuine that they refer to some objective reality, but, of course, they do not. They are part of a social process through which we define some children as different from others. Yet images that establish difference-or sameness-may reveal more about those who invoke the images than about those to whom they refer.

The term "handicap" is one of the more prominent cultural constructs that we use to define and categorize children who are different, yet it increasingly has fallen into disfavor. ${ }^{82}$ Commentators have attempted to distingnisli the physiological or "objective" referents of the term "handicap" from the cultural or social preconceptions with which those referents are associated. Some have argned that the former, as opposed to the latter, are more appropriately characterized by terms sucl as "disability" or "impairment." For example, Beatrice Wright defines "pliysical disability" as a "limitation of function that results directly froin an impairment at the level of a specific organ or body system," whereas she defines "handicap" in terms of social interaction as "the actual obstacles the person encounters in the pursuit of goals in real life, no matter what their source."83 In this sense, "handicap" denotes the range

80. See generally O. SACKS, supra note 75 , at 178-186 (using a patient's story to reflect Sacks' frustration with defectology).

81. Indeed, the concept of "defect" also implies the concept of a "perfect" child who has no defects. How such a child might look or act is itself a cultural construct.

82. This is evident from the fact that Congress replaced the term "handicap" with the term "disability" in its 1990 amendments of the EHA. See supra note 32.

83. B. Wright, Physical Disability-A Psychosocial Approach 11 (1983). The IVorld Health Organization recommends a tripartite definitional scheme that distinguishes among "impairment" ("any loss or abnormality of psychological, physiological, or anatomical structure or function"), "disability" ("any restriction or lack (resulting from impairment) of ability to perform an activity in the manner or within the range considered normal for a human being"), and "handicap" ("a disadvantage for a given individual, resulting from an impairment or a disability that limits or 
of difficulties that flow from a physical disability, many of which originate in culturally based assumptions, judgments, or biases concerning the appropriate social role of a disabled person.

Even these distinctions are not entirely persuasive, because they are based on the assumption that physical disabilities are not themselves cultural constructs. It would seem obvious that concepts concerning "limitation of function" vary according to the kinds of function a society considers signiflcant. Wright herself cites the example of foot binding ainong Chinese woinen, whicl was considered at one time to be a inark of nobility, but which conteinporary American society probably would regard as an important limitation of function. ${ }^{84}$ Victor Finkelstein illustrates this argument by imagining a world designed and inhabited primarily by wheelchair users. In that world, he observes:

Door and ceiling heights ... could be lowered substantially. If, now, able-bodied people were to live in this community they would soon find that they were prevented from "normal" social intercourse-they would be constantly knocking their heads against the door lintels! Apart from bruises the able-bodied would inevitably find themselves prevented from using the wheelchair-user-designed environment and aids. They would lack jobs and become impoverished-they would becoine disabled 85

Pliysical disabilities and the handicaps tliat flow from them are, in large measure, "social constructs." 86 They are perceived and understood in terms of prevailing cultural conceptions of normal pliysique and physical function and of the significance of any deviation from that norm. In American society, many different concepts of normality and difference affect perceptions of people defined as physically "handicapped." Erving Goffman argued that pliysically disabled persons are stigmatized on the basis of their "spoiled" social identities, just like otliers who deviate from "normal" expectations on the basis of such factors as race, ethnicity, religion, listories of criminal behavior or mental illness, homosexuality, drug addiction, and prostitution. 87 Physical disabilities often are perceived in the same terms as coinmunicable diseases ("Tley act like it's

prevents the fulfilment of a role that is normal (depending on age, sex, and social and cultural factors) for that individual'). WORLD HEALTH ORGANIZATION, INTERNATIONAL CLASSIFICATION OF IMPAIRMENTS, DISABILITIES, AND HANDICAPS 27-29 (1980).

84. B. WRIGHT, supra note 83 , at 11 .

85. V. Finkelstein, ATtitudes AND Disabled People: IsSUes for Discussion 34 (1980).

86. J. Gliedman \& W. Roth, THe UneXPected Minority: Handicapped ChildRen IN AMERICA 13-30 (1980).

87. E. Goffman, Stigma: Notes on the Management of Spoiled Identity (1963). 
contagious"88) or as phenomena likely to "spread" to other aspects of the personality, such as cognitive or social processes ("I expected his thoughts to be jerky also"89). Physically disabled persons are viewed with fear and revulsion because they occupy an anomalous social position:

They are not ill, for illness is transitional to either death or recovery.... The sick person lives in a state of social suspension until he or she gets better. The disabled spend a lifetime in a similar suspended state. They are neither fish nor fowl; they exist in partial isolation from society as undefined, ambiguous people. 90

Stignia, fear of contagion, stereotyping, and rejection have thus typified the responses of "normal" society to those labelled physically "handicapped."

For children with disabilities, the ubiquitous "telethons" and the campaigns for charitable contributions by various children's organizations disseminate another important set of cultural images. Often, the symbols used to encourage donations suggest that children with disabilities, although "cute" (at least when they are young-teenagers or adults with disabilities may be less appealing), are dependent on the good will of others. Objects of pity, they are "brave" or "courageous" as they struggle under the crushing burden of their disability. Encouraged to feel grateful that their own children are "healthy," donors pledging their money may distance themselves and their "normal" world from the children they assist.

\section{B. Conceptions of "Handicap" and Encounters Between Parents and} Educators

Parents and Cominittee members interact in a cultural milieu pervaded by these and other perceptions of "handicapped" children. These perceptions and classification systems inevitably influence their thoughts about the child, his or her relationship to other "normal" children, and the kind of program suitable for one who is "different" in some respects but not in others.

88. Scheer, "They Act Like It's Contagious": A Study of Mobility Impairment in a New York City Neighborhood, in Social Aspects of Chronic Illness, Impairment and Disadiltty 62 (1984).

89. B. WRIGHT, supra note 83, at 61.

90. R. MURPHY, THE BODY SILENT 131 (1987). The stigma and social isolation associated with disabilities are often connected to imagery of contagiousness, whether real or imagined. The Supreme Court recently noted that "[t]he isolation of the chronically ill and of those perceived to be ill or contagious appears across cultures and centuries, as does the development of complex and often pernicious mythologies about the nature, cause, and transmission of illness." School Bd. v. Arline, 480 U.S. 273, 284 n.12 (1987). 
One mother and father described the classification and placement process that their son underwent when he left his preschool program for kindergarten. During initial contacts with Conımittee personnel, the child, whose diagnosis clearly specified physical but not cognitive impairment, was persistently steered away from placement in a regular kindergarten classroom with "normal" children. ${ }^{91}$ Even after a member of the committee observed him in his fully integrated preschool setting, she recommended placenient in a self-contained kindergarten classroom with learming disabled children who were two and three years older than he. Because of his physical disabihty and his need for certain support services, such as physical therapy, his "difference" was perceived as significant enough to preclude grouping him with "normal" children.

This deeply conditioned response to physical disabilities was not uncommon among the CSEs studied. The case mentioned above was resolved quickly because the parents were unusually combative and other menibers of the CSE eventually intervened on their behalf. Solne cases, however, lead to protracted and bitter struggles. A family whose academically gifted child suffered a seriously debilitating physical injury had to battle their committee over an extended period of time before the CSE agreed to placenient in a regular classroom with appropriate support services. The CSE chair suggested that the difficulty in this case arose because the district did not have any experience with "a very bright handicapped child." He explained that "special education really is not set up to deal with an intelligent handicapped child. ... In other words, the physically handicapped person is autoniatically retarded."92

It is difficult to believe that a school district had never encountered an intelligent child who was classified as "handicapped." The assumption appears to be that a child can be either intelligent or "handicapped" but is rarely-if ever-both. The concept of difference becomes all-consuming, and a purely physical disability creates a perception that the child's social identity is "spoiled" in every respect. ${ }^{93}$

Cultural conceptions of "handicap" affect parents as well as Committee menibers. Some parents agreed that the dichotomy between "handicapped" and "non-handicapped" children was real and significant. In part, this was because they feared that, if the distinction were not drawn, their child might be placed in situations that he or she was not equipped to handle. For thein, the term "handicapped" was necessary to mark a difference between their child and other children and to

91. Interview with "Doris and Robert Moore" (July 27, 1988).

92. Interview with Chair of CSE for School District "A" (Apr. 15, 1988).

93. See E. GofFMAN, supra note 87, at 2-19 (showing how social identity is "spoiled" by stigmatizing characteristics such as physical disability). 
justify the provision of special education services that would enable their child to function in a school environment. Further, some parents were aware of literature ${ }^{94}$ that stressed that they should not "deny the handicap" but should accept this description of their child and cope with it in a positive way. Parents familiar with this literature sometimes wanted to demonstrate their passage beyond the "denial" phase of raising a child who had disabilities.

Other parents, however, rejected the use of concepts that suggested a sharp dichotomy between their child and other children. For them, all children were situated at different points along the same continuum. Different strengths and weaknesses could be found, but all shared many important attributes simply because they were children. These parents resisted any characterization of their child that denied the important cominonalities that linked him or her to children who were not labelled "handicapped." For this latter group, prevailing conceptions of "handicap" clashed with their own experience. They simply did not perceive or interact with their child primarily in terms of the disability, and they felt uncomfortable with cultural images that clashed with their own experiential reahity. Additionally, such characterizations of their child seemed to imply the acceptance of limited goals and aspirations. In the words of one mother:

I don't like the word "handicapped".... I don't use it a lot. It's like a big word that says "no." Not that this is something that's hard for her to do now, but when you say "handicapped" this is something like a sign that says, "No, you can't do it. Don't even try for it."95

Perceiving children with disabilities in terms of either a dichotomy or a continuum profoundly affected how parents participated in CSE planning. The greater the shared perception that the disability sharply differentiated their child from other children, the more plausible and acceptable were the suggestions to segregate the child educationally from other children on the basis of the disability. If, however, parents perceived their child more in terms of qualities shared by all children, then these recommendations appeared inappropriate and subject to challenge.

94. See, e.g., V. HeISLER, A HANDICAPPEd ChILd in the FAMILY: A Guide For PARENTS 41-42 (1972) (parents weaken and limit themselves by denying the existence of their child's "handicap"); J. MCNamara \& B. MCNamara, The SPECIal Child HandbooK 90-91 (1977) (advising parents to pass beyond "denial" of their child's "handicap" in order to help the child adjust); E. Webster, Counseling With Parents of Handicapped Children: Guidelines for IMPROVING COMMUNICATION 40-41 (1977) (summarizing the four stages of reaction to the discovery of a disorder: shock, realization, defensive retreat, and acknowledgement); Murray \& Cornell, Parentalplegia, 18 Psychology IN THE ScHools 201-02 (1981) (parents who fail to accept and adjust to the "handicap" can create emotional problems in their children).

95. Interview with "Valery Reich" (June 24, 1988). 
Under the EHA, parents easily find themselves in a double-bind, which forces them to stress simultaneously the similarities and differences of their child. They may argue for an integrated setting as the "least restrictive environment" by stressing how similar their child is to the other children, but there are dangers in pushing such arguments too far. They inust also demonstrate that their child is sufficiently "handicapped" to justify the support services that will permit him or her to function in the less restrictive setting. The benefits of the EHA are available only to those who can make such a showing.

In effect, parents who seek less restrictive placements for their children are required to draw selectively on two somewhat inconsistent sets of cultural images and assumptions about difference. This presents some complex and difficult challenges. At best, it makes the process of parental participation in CSE meetings confusing. At worst, the decision to stress one set of images at the expense of the other could prove disastrous. The artificiality of the process of description and classification makes many parents uncomfortable. In my study, it was not unusual for parents to deal with their discomfort by bringing large photographs of their children to show the Committee, as if to say, "This is the reality of iny child as I know her. This is the human being that eludes the concepts and terminology employed in these meetings." But when I asked some of these parents how the Committee mernbers responded to the photographs, I was told that there was little reaction other than an occasional comment on how cute their children were. Even photographic images of the children were interpreted according to the preconceptions of the observer. The parents who searched for some bedrock of objective, universally acknowledged reahty found only an additional layer of culturally conditioned symbols and meanings that they had to debate and negotiate with their committee.

Parents and CSE members tend to view children with disabilities in different ways and to interpret "handicap" according to different images and assumptions. Because they perceive the child through different lenses, they tend to draw conflicting conclusions about the significance of the child's disability. The clash between the perspectives of parents and professionals is addressed in the discussion that follows.

\section{Parents and Professionals}

Few parents of children without disabilities would expect to meet with their child's teacher before the school year begins and to cooperate in the creation of an educational plan uniquely suited to their child's needs. Nor would most teachers welcome this degree of parental involvement. Yet, once a child is classified under the EHA, parents and 
educators are placed in precisely this position. Rather than meeting alone with the new classroom teacher, however, the parents generally sit at a large table with a number of professionals trained in such diverse disciplines as psychology, nursing, social work, medicine, and special education. The situation is no less strange for the professionals than for the parents. The EHA has brought them together, but it has told them little about how they should proceed to attain the elusive goal of an "appropriate" education.

It is not surprising that, even within a single geographical region, different school districts developed very different approaches to the IEP conference. CSEs in western New York range in size from four or five members to twenty or more. Most have only one parent representative at each IEP meeting, ${ }^{96}$ but some include a parental majority. Most committees operate primarily on the basis of pre-meetings, essentially rendering the meeting itself an empty formality. A few deliberately avoid premeetings. Some committees draft the IEP before the meeting and before obtaining the parents' input. Others draft the IEP during or-more typically-after the meeting. Some committees prepare for the meeting with extensive conferences with the parent, during which test results and recommendations are discussed. Others withhold such information until the nreeting itself. Some committees reach decisions by consensus, others by vote, and sonie make their decisions only after asking the parent to leave the room.

Despite these differences, certain commonalities are apparent. Most parents describe themselves as terrified and inarticulate. Some liken themselves to prisoners awaiting their sentence, and this courtroom imagery emphasizes their perception of the judgmental rather than cooperative quality of the decisionmaking as well as their feelings of vulnerability and disempowerment. In almost all the districts, parents receive little help from the parent representative on the committee, who usually remains silent. Often, but not always, parents feel that their own observations or requests are given little weight and that decisions are based priniarily on the reconımendations of the professionals. Their own close relationship with the child is viewed as a liability rather than as an asset-a liability that renders their judgments inherently suspect. Some committee chairpersons described with consternation the tendency of the majority of parents to stop attending the annual review meetings after the first few years. Non-attendance is predictable, however, in light of the

96. As mandated by N.Y. Educ. LAw § 4402(1)(b)(1) (McKinney 1990). 
stress, frustration, and anger expressed by parents in one interview after another. ${ }^{97}$

Perhaps the inost basic issue in the unusual cooperative decisionmaking process established by the EHA is the kind of contribution that parents and professionals can and should inake. Parents know the child better than anyone, but in inost cases they lack specialized training in education or related disciplines. Professional members of the committee have such training, but they generally lack personal fainiliarity with the child. Further, documents in the child's committee file are predominantly based on quantitative measures derived from standardized tests rather than qualitative interpretations or assessinents. Thus, parents and professionals differ in their backgrounds, personal knowledge, and their views on which factors accurately describe the clild's qualities and capacities.

Because the professionals base their interpretations and their decisions on a language and a knowledge system that parents do not usually understand, they tend to assuine that parental input will be inisinformed or erroneous. Consequently, there is widespread suspicion of the very element that inade the EHA unique-parental involveinent. The chair of one prominent CSE in the region coinpared the problem to that of a patient's inability to participate effectively in decisions about his or her own medical treatınent:

I think this law has forced [parents] into thinking that they could really have a true partnership with the professionals. . . . But I think personally it's somewhat unusual to expect. It's like saying to you, you can have a partnership with the doctors who are going to treat you. You should have just as much say in all of your treatments. You can't really have as much say because it's too complicated..$^{98}$

This speaker's perceptions derive from a dichotonized view of the realins of the professional and the layperson. Even her assuinptions about the necessarily passive role of patients in medical decisionmaking would meet with disapproval froin many quarters. Yet, her viewpoint is shared widely by both professionals and parents. Consider the following statement by the mother of a seven year-old boy classified as "multiply handicapped":

97. This research was designed to study parent-CSE interactions in light of the goals of the EHA and not to survey overall parental satisfaction with the CSE process. Focused as it was on parents of children with physical disabilities, moreover, the research did not tap the attitudes of the far more numerous parents of children with classifications other than "orthopedieally impaired" or "multiply handicapped." There are some findings that indicate that such parents (e.g., parents of children receiving only speech therapy) are generally satisfied with the special education process. See Singer \& Butler, The Education for All Handicapped Children Act: Schools as Agents of Social Reform, 57 HARV. EdUC. REV. 125, 142 (1987).

98. Interview with Chair of CSE for School District "B" (May 26, 1988). 
I don't know if I have a choice [about my kid's program], but then-to be honest with you-I'm kind of glad I don't, because I don't want to make the wrong one anyway. I'd rather have the choice left to somebody else. ... I'm so unschooled as far as the therapies and the teaching and whatnot. I don't thimk I'm in a place to judge whether or not he's receiving the right thing. ... Getting him up, getting him dressed, and sending him to school. That's my job.99

One can easily imagine the kind of interaction that would occur if this particular mother and CSE chairperson were sitting at the same conference table. Regardless of the degree of sensitivity to the mother's feelings, or the extent to which programming options were explained to her, both sides would assume that substantive decisions properly were the responsibility of the tramed professional. From this perspective, the involvement of the parent in the IEP conference serves an informational function at best. As some CSE chairs explained, children are more likely to succeed if parents understand and acquiesce to program decisions. This does not mean, however, that parental participation in such decisions is either desirable or appropriate.

The CSE chairs who participated in this study were read the statement by "Rachel Dolan" quoted above ${ }^{100}$ and were asked for their response or reaction. One CSE chair from a rural school district observed, "That's a very intelligent approach to education. I wish more people felt that way. ... We are fallible too, but maybe we are a little better [able] to make a judgment than parents."101 When asked whether, on the whole, he would consider this parental attitude an advantage or a disadvantage in working to achieve an "appropriate" education for the child, this CSE chair responded with another analogy to professional decisionmakingnot medical treatment in this case but legal counseling:

I call that a plus, myself.... They go to you for legal services and legal advice, you would expect them to follow through with what you say. They come to us for educational services and educational advice, based on our experience and knowledge of options, I would expect that they would follow what we have to say. ${ }^{102}$

99. Interview with "Rachel Dolan" (Oct. 27, 1987).

100. See supra text accompanying note 99.

101. Interview with Chair of CSE for School District "A," supra note 92.

102. Id. Some empirical studies of attorney-client interaction suggest that the decisionmaking process is indeed one-sided and is, for a variety of reasons, dominated by the professional. See, e.g., D. Rosenthal, Lawyer and Client: Who's In Charge? 143-44 (1974); Blumberg, The Practice of Law As Confidence Game: Organizational Cooptation of a Profession, 1 LAw \& Soc'Y Rev. 15, 32-39 (June 1967); Hosticka, We Don't Care What Happened, We Only Care About What is Going to Happen: Lawyer-Client Negotiations of Reality, 26 Soc. ProBS. 599, 601-05 (1979). Many commentators, however, now take the position that the client should be an active participant in making decisions in his or her ease. See D. Rosenthal, supra, at 154-61 (1974); Luban, Paternalism and the Legal Profession, 1981 WIS. L. REV. 454, 493 (endorsing client's right to decide unless his or her ends are "self-destructive"); Mazor, Power and Responsibility in the Attorney-Client Rela- 
The rigid dichotomization of parental and professional roles in the IEP process appeared in many of our interviews. This dichotomy reflects a fundamental cultural understanding of professionalism in general and of the specialized traiming necessary to deal with "handicapped" children in particular. It should also be emphasized, however, that CSE chairs did not always respond to the mother's statement with unqualified approbation. Some viewed the statement favorably, but did not necessarily believe that all parents should adopt "Rachel Dolan's" position. One CSE chair estimated that sixty percent of the parents in her district shared this perspective and observed that if they wished to remain passive and place their "trust" $m$ the CSE then she was quite willing to go along:

That parent, in my opinion, has a big trust factor, and perhaps that parent through his or her own school experience or the experience of other children in the family and relatives and hearsay and all that in the community and the neighborhood may feel justified in saying that. And if they're comfortable with that, that's fine, as long as they've had the opportunity to share and ask questions. ${ }^{103}$

For this CSE chair, educational success could be achieved without active parental participation as long as the parents "trusted" the professionals to make the correct decisions for their child.

Other CSE chairs responded more cautiously. One, for example, stated that she found "educated" parents hard to work with because they come to the IEP process with their own strong ideas about what they want for their child. And yet, in response to "Rachel Dolan's" statement quoted above, she responded emphatically that she would refuse to accept it. She personally would encourage the parent to examine different options and would help the parent to choose among them. The reason, as she expressed it, is that the uninvolved parent may be a potential source of trouble for the CSE, particularly if he or she later becomes dissatisfled with the child's placeinent or program:

A month later that parent is not happy with it, because she nieets another person at the supermarket. And "Jane" says, "Oh no, I don't send my child to that progranı. I send to this one. This one's so niuch better for language." Now that parent is pretty soon talking around town. "Do you know what this conımittee did? This comnittee sent

tion, 20 STAN. L. REV. 1120 (1968) (tracing developments in attorney-client relationship regarding negligence, malpractice, and use of authority against the background of changing societal views about responsibility and autonomy); Spiegel, Lawyering and Client Decisionmaking: Informed Consent and The Legal Profession, 128 U. PA. L. REv. 41, 73-77 (1979) (strongly held values related to the operation of the legal system and to the relationship between lawyer and client support a presumption of client control).

103. Interview with Chair of CSE for School District "C" (Apr. 27, 1988). 
my kid to BOCES 2, and Jane's kid goes to Language Development." And they will do that. ${ }^{104}$

For this CSE chair, parental involvement is important to prevent the parent from subsequently attacking the Committee for its decision and thereby discrediting the Committee in the community. This is not to say, however, that she welcomed substantive input from the parent; her observations about the troublesome impact of the educated parent suggest otherwise: "Today they're almost getting too educated the wrong way." 105

A few CSE chairs rejected the dichotomization of professional and parental roles. One CSE chair stated that she would respond to the mother's statement by reminding her of the importance of the contributions she had already made to the IEP process and of the role she should play in all decisions affecting her child. The parent should feel that "we're not these gods that know more than she does."106 The parent's knowledge of the child is important and valuable despite the lack of professional training, and the parent should not abdicate her decisionmaking role to the specialists: "I want the parent to be involved, to share the success or the failure of their child's school program."107 It is probably not a comcidence that this CSE chair reported an unusually high parental attendance rate at IEP conferences.

CSE practices, as well as the observations of the CSE chairs, reveal diverse assumptions about parental and professional input. The CSE chair froin school district " $E$ " (quoted immediately above) never holds premeetings, because that "wipes out the purpose of the committee meeting." 108 If discussions and recommendations precede the meeting itself-particularly if the parent is not present when they take place-then the importance of parental participation is implicitly undercut. Another CSE chair insists on writing the IEP by hand during the meeting, while sitting next to the parents and going over each statement and recominendation with them. This approach, which emphasizes the parents' involvement in each decision, is very unusual. More typically, the IEP is drafted either before the meeting-and then approved or amended as a result of the meeting - or is written after the meeting and mailed to the parent.

The attitudes and behavior of parents and educators are greatly influenced by views of professional dominance in the decisionmaking pro-

104. Interview with Chair of CSE for School District "D" (Mar. 25, 1988).

105. Id.

106. Interview with Chair of CSE for School District "E" (Feb. 3, 1988).

107. Id.

108. Id. 
cess. For example, one young mother beheved that her "multiply handicapped" child, who was on the verge of independent ambulation with a walker, should receive physical therapy three times each week rather than twice. Many children in other districts received physical therapy three times a week with less justification, thus nothing seemed unreasonable about her suggestion. Yet the response of the CSE chair during the IEP meeting simply was, "Sarah [the therapist] feels two times is enough."109 That was the end of the discussion. The professional opinion standing alone, without any supporting rationale, was sufficient to rebut the parent's suggestion, and the parent was dismchined to pursue the matter. At a subsequent IEP meeting, the committee unilaterally increased her child's speech therapy from three to five times per week. ${ }^{110}$ In the past, she had requested this increase, but the request had been ignored.

Some parents act more assertively than others, but assertiveness does not necessarily lead to greater involvement in the decisionmaking process. One parent, convinced that parental contribution was crucial to achieve an "appropriate" education, stated: "I really think that unless you open your mouth and you fight, you have no say on what goes on with your kid."111 Yet she felt strongly intimidated "every time I get with any of those suit-and-tie guys" because of their superior education and training. ${ }^{112}$

This mother fought the committee and prevailed concerning the placement of her child. But a year later, she did not feel that the victory had earned her any greater acceptance by the professionals on the committee. She was infuriated by the patronizing tone with which they still addressed her:

They questioned the previous year, why I had fought it [their recommendation].... You try to explain to them that you do live with your child twenty-four hours a day. ... And the guy started putting me down that it was my insecurities.... Well, he said, are you sure last year it wasn't that "Mother" was afraid to let her go? .. . You can call me anything, but don't talk down to me. That makes me so mad!113

There are several reasons why parental knowledge and recommendations carry less weight than professional knowledge and recomnienda-

109. Interview with "Christine Hibbard" (May 9, 1988).

110. Interview with "Christine Hibbard" (July 28, 1988).

111. Interview with "Valery Reich" (Sep. 21, 1987).

112. Id. The allusion to differences in social class should not be ignored in such statements. Class differences were significant in the interactions between Committee members and many parents. These differences played themselves out in complex ways. This factor will be considered in grcater depth in future analyses of the interview data.

113. Id. 
tions in the IEP process. One is sheer numbers. The parents are outnumbered and surrounded at the big table by the professionals. Members of an ongoimg team with its own internal dynamics, the professionals are more reluctant to oppose one another than to oppose the lone "outsider." Parents are inherently suspect because of their emotional attachment to the child, and CSE members assume that parental preferences reflect subjective rather objective judgments. Since more is at stake for them than for anyone else at the table, parents generally are anxious and marticulate. They are often less educated than other CSE members and are non-conversant in the technical language or concepts used during the meeting.

For these reasons, parents occupy an ambiguous and ill-defined position in CSE meetings. In social and cultural terms, their power and authority relative to the other CSE members is small. In legal terms, however, their power is great. Yet this is a form of power without cultural precedent: No cultural images correspond to the control parents can exercise over the CSE decisionmaking process. Traditional imagery of educational authority and of the superiority of "scientific" knowledge tend to disempower parents. What they lose during interactions at the conference table, however, could im theory be recouped by asserting legal challenges afterward. The reason such challenges seldom are raised will be explored in the following discussion of rights and relationships.

\section{RIGHTS AND RELATIONSHIPS}

The EHA was an outgrowth of the premise, articulated in Brown v. Board of Education, that education is a "right which must be made available to all on equal terms."114 The EHA affirmed that "handicapped". children were equally entitled to this important right regardless of their disability. ${ }^{115}$ Further evidence of the rights-based foundation of the EHA appears in the guarantee of a supplementary set of rights to children classified as "handicapped." These include the broad right to an "appropriate education" in the "least restrictive environment" with the provision of "related services" and the full panoply of procedural protections to safeguard the basic entitlement. ${ }^{116}$ As in the struggle against racism, advocates and policymakers chose to combat discrimination by a guarantee of legal rights-the most basic being the right to education.

114. 347 U.S. 483,493 (1954).

115. See 20 U.S.C.A. $§ 1400$ (c) (1990). Following the 1990 amendments to the EHA, this provision now refers to the rights of "children with disabilities" rather than "handicapped children." See supra notes 1 and 32.

116. See 20 U.S.C.A. $\S \S 1400,1401,1414-15$ (1990). 
The actual workings of the EHA, however, are strongly influenced by culture, ideology, and power. Interviews with parents and educators revealed that concepts of "rights," like the concepts of "handicap" and parental participation discussed above, were problematic and culturally contingent. The EHA created a painful dilemma for the parents who considered invoking a rights-based analysis of their child's educational needs.

The concept of "rights" is not a universal constant but a particular cultural perspective on individuals and social relationships. Many people in our society autonatically frame legal issues or conflicts in terms of the rights vested in one or both of the parties involved. This intuitive gravitation toward rights analysis can be puzzling or incomprehensible to persons living in other societies where different cultures and worldviews are found. ${ }^{117}$ Alternatives to rights analysis can be found in our society as well. In Carol Gilligan's study of moral reasoning and development, for example, she discovered not one but two voices among her interview subjects: "One voice speaks about equality, reciprocity, fairness, rights; one voice speaks about connection, not hurting, care, and response."118

The "other" voice, which was predominantly but not exclusively a female voice in Gilligan's study, tends to emphasize relationships rather than rights and interconnectedness rather than individual autonomy. ${ }^{119}$ Viewed from this alternative perspective, moral dileminas or conflicts require that individuals try to understand and respond to the concerns of another person, rather than simply engaging in reasoned discourse about their own claims or entitlements. A detached insistence upon individual rights in such a situation, without attending to the perspective of others who might be involved, struck some of Gilligan's interviewees as uncaring and selfish. ${ }^{120}$

In a recent book, Martha Minow explores the inplications of rights analysis and its alternatives with respect to persons with disabilities-in particular, developmental disabilities. ${ }^{121}$ She suggests that the emergence of rights analysis provided an alternative to the traditional "abnormal persons" approach, a perspective rooted in the feudal hierarchical or-

117. See, e.g., D. Engel, Code and Custom in a Thai Provincial Court 63-68 (1978); Pannikkar, Is the Notion of Human Rights A Western Concept?, 120 Diogenes 75 (1982).

118. Marcus, Spiegelman, Du Bois, Dunlap, Gilligan, MacKinnon, and Menkel-Meadow, Feminist Discourse, Moral Values, and the Law-A Conversation, 34 Buffalo L. Rev. 11, 44 (1985); see also C. Gilligan, in A Different Voice: Psychological Theory and Women's DevelopMENT (1982).

119. C. Gilligan, supra note 118 , at 19.

120. See generally id. at 24-63.

121. M. Minow, Making All the Difference: Inclusion, Exclusion, and American LAW (1990). 
der. ${ }^{122}$ The "abnormal persons" approach assumed that a clear dichotomy existed between the mentally competent and the incompetent, and that a fundamentally different legal treatment was therefore justified for those deemed "abnormal."123 Rights analysis, on the other hand, emphasized the apphicability of certam fundamental legal entitlements-includimg the right to education-to all persons, whether disabled or not. ${ }^{124}$ This approach was advocated in the disability rights movement of the 1960s and 1970s and shaped PARC and Mills as well as the draftmg of the EHA. ${ }^{125}$

Minow suggests that the logic of rights analysis can lead to certain limited and unsatisfactory conclusions concerning the social position of persons with disabilities. ${ }^{126}$ If one pursues the strand of rights analysis that emphasizes "sameness" between persons with and without disabilities, one might successfully challenge inappropriately segregated educational facilities. But it then becomes difficult to frame consistent arguments for differentiating disabled from non-disabled persons in "mamstreamed" settimgs and to provide support services as a matter of right only for persons with disabilities. If, on the other hand, one pursues the strand of rights analysis that emphasizes "difference"-the particular entitlements that are based on the special needs of persons with disabilities-then it becomes more difficult to oppose placement in specialized settings apart from the community. ${ }^{127}$ Rights analysis, when applied to persons with disabilities, thus contains contradictions that make it difficult to comprehend both sameness and special entitlements, both difference and shared humanity. ${ }^{128}$

The individualized focus of rights analysis can wrench the person with a disability out of the context of human relationships that are vital to his or her survival as a social being. Rights analysis tends to suggest claims agamst persons or groups rather than shared concerns. The emphasis on autonomy precludes any clear image of the links that should and must exist between the individual and the community. ${ }^{129}$

122. See id. at 105-08, 131-35.

123. See id. at 124-27.

124. Id. at $107,136$.

125. See Mills v. Board of Educ., 348 F. Supp. 866 (D.D.C. 1972); Pennsylvania Assoc. for Retarded Children (PARC) v. Commonwealth of Pennsylvania, 343 F. Supp. 279 (E.D. Pa. 1972); see also M. Minow, supra note 121, at 134-36.

126. See M. MiNow, supra note 121 , at 108-10, 137-39.

127. See id. at $144-45$.

128. See infra text accompanying notes 130-37.

129. Minow also describes a third possible approach (the "social-relations approach") which, although somewhat undefined, could address some of the problems raised by the abnormal persons and rights approaches: 
Minow's critique finds an application in the day-to-day experiences of parents of children with disabilities. For them, rights analysis sometimes offers an escape froin intractable conflicts with school districts, but it carries with it a vision of individual autonomy and a lack of connectedness that is antithetical to their image of the child's place in the community.

Consider, for example, the perspective of the mother of the "multiply handicapped" child, inentioned above, ${ }^{130}$ who uses a wheelchair but is on the verge of standing and walking with a walker. The child now receives physical therapy twice a week. The inother feels that her child should receive physical therapy as often as five times a week to increase her potential for independent ambulation. As soon as she inentions this preference, however, she hastens to add: "That's being selfish . . . because that's thinking of my child and not of other children."131

This mother does not conceptualize her child's situation in terms of "rights" that could be asserted within the special education system. Rather, she thinks in terms of her child's relationship to all the other children who receive therapy. She reasons that only a finite number of therapist hours are available for all the children and that an increase for her child would inean a decrease for some other child. Thus, to insist on her child's "right" to additional therapy would be "selfish."

It is important to note that the design of the EHA should prevent this sort of trade-off among children who require related services. IEPs must be "individuahzed," and therapy levels for each child should be determined by what is appropriate for him or her without reference to the needs of other children in the same district. Most observers would

\footnotetext{
Unlike rights analysis, but bearing some resemblance to the concept of abnormal persons, the social-relations approach assumes that there is a basic connectedness between people, instead of assuming that autonomy is the prior and essential dimension of personhood. Yet like rights analysis and unlike the concept of abnormal persons, the social-relations approach is dubious of the method of social organization that constructs human relationships in terms of immutable categories, fixed status, and inherited or ascribed traits.

M. MiNow, supra note 121 , at 110 .

The social-relations approach focuses on the interplay between different groups in society. It assumes that the ways in which such groups are defined is socially determined rather than resting on immutable, universally-acknowledged differences among human beings. Its goals include a continuing effort to ensure that the interactions between such groups protect the weaker against the stronger and tend to benefit rather than harm those who are most vulnerable:
}

As a method of legal analysis, the social-relations approach demands analysis of difference in terms of the relationships that construct it. . . Besides identifying avenues for inquiry about difference, the social-relations approach points toward a particular, normative evaluation of legal assignments of difference: attributions of difference should be sustained only if they do not express or confirm the distribution of power in ways that harm the less powerful and benefit the more powerful.

Id. at 112 .

130. See supra text aceompanying notes 109-10.

131. Interview with "Christine Hibbard" (July 28, 1988). 
agree that, despite the mandates of the EHA, short-staffed service providers and school districts with limited funds make such trade-offs implicitly. ${ }^{132}$ Yet, the parents are empowered by the EHA to serve as a check on such tendencies and to safeguard the rights of their child. When parents themselves perceive the assertion of individual rights to be "selfish" and anti-commumitarian, however, cultural views of social relationships dramatically reshape the imtent of the original statute.

My research tended to support the assertion of many educators that it is usually the mothers and not the fathers who deal with school districts on behalf of their children. ${ }^{133}$ In light of Gilligan's finding that the "other" voice typically is a female voice, we might expect that the tendency of motliers to invoke a "rights analysis" would be muted. There were, indeed, inany instances when mothers drew back from an assertion of rights. For example, I interviewed a motler wlose multiply handicapped daugliter recently underwent surgery. Before the cliild could return to scliool, in-service traiming for school personnel had to be arranged so that they could manage some of tlie particular needs resulting from the surgery. The CSE chair neglected to arrange such training for a number of weeks. As a result, the clild reinained idle at loone, deprived of contact with any otlier children. In the meantime, despite the mother's repeated requests for immediate action, tlie cliairperson did nothing more than to provide an lour per day of hoine teaching for the child.

The mother knew that slie could clain an infringement of her daughter's legal rights. Indeed, slie knew of an advocate wlio might-for no fee-have asserted a claim on her belialf. But slie liesitated to call the advocate: "She's so busy. I figure I just liave 'piddly' questions." 134 Instead, sle contacted the CSE cliair once again and inade the following offer: "I said, teinporarily, until you get this set up, I'll come to the school and I'Il be lier bus aide and I'll be lier scliool aide and I'll care for her hike her nurse, just so she could go to scliool."135 This arrangenent would have involved significant costs to the mother, wlio held two jobs and cared for a second cliild. Slie would have had to resign froin one of her jobs, appear an hour late for her second job, and hire a babysitter for her younger child.

132. Cf. P. Hill \& D. Madey, Educational Policymaking Through the Civil Justice SYSTEM 25-26 (1982).

133. By contrast, the CSE leadership appeared to involve men and women in roughly equal numbers. Among the 22 school districts in which we interviewed parents and/or school district officials, the CSEs were chaired by men in ten districts and women in twelve.

134. Interview with "Martha Freedman" (Sep. 30, 1988).

135. Id. 
What perspective on the educational rights of children led this mother to make such an extraordinary concession when she believed the CSE chair was entirely in the wrong? Later in the discussion, she made her position clear: When there is conflict between a parent and the CSE chairperson, it is best to seek a solution half-way between the two positions. I asked if she meant that there should not be situations where either the parent or the CSE chairperson actually wins an outright victory. She agreed emphatically: "I don't think that's right either, because what if my decision was wrong?"'136

What is striking here is the strong gravitation toward compromise solutions (in this case amounting to a unilateral capitulation) rather than the vindication of legal rights. It also is apparent that this mother, like many others, intuitively defined an incipient conflict in terms of niaintaining her relationship with the other party rather than asserting claims against that party. Like Gilligan's interviewees, she attempted to view the problem from the other side's perspective as well as her own. ${ }^{137}$ After all, the CSE chair's position may also be valid-perhaps more valid ("what if niy decision was wrong?"). This articulation of the "other voice" coexisted somewhat tenuously in the mother's mind with the simultaneous recognition that the CSE chair was behaving unreasonably and that her child's legal rights probably were being violated. Yet the "other voice" was strong enough to lead her to offer an extraordinary concession rather than to avail herself of the procedural protections afforded by the EHA.

This emphasis on relationships rather than rights characterized many-but not all-of the parents who participated in the study. Some parents were interviewed specifically because they had sought the assistance of a legal advocate. ${ }^{138}$ Generally, these parents were enthusiastic about the results of their strong assertion of rights in situations where they felt the CSE had acted inappropriately. In some instances, these parents sought and obtained moral vimdication: Their child was treated unfairly, and rights analysis demonstrated to the CSE that its behavior was iniproper. In other instances, however, parents extolled the assertion of rights not because it ultimately vindicated their position but because it improved the relationship between the disputants. The "Peterson" fanily had two children, both of whom were classified as "handicapped." 139 Dealings between "Julia" Peterson and the CSE chair

136. $I d$.

137. See C. GlLLigan, supra note 118 , at 62-63.

138. For an account of the interview sample, see supra note 6.

139. Mr. and Ms. "Peterson" were both high school educated. Mr. Peterson was a factory worker, while Ms. Peterson worked at home. 
concerning the first child had been stormy: "We had many confrontations on the phone, and I would be crying. ... She would try to sidetrack me, and then her tone would change and then my tone would change, and there would be a blowup over the phone and we didn't get anywhere." 140

Conflict with the CSE chair distressed Ms. Peterson, not only because of the emotional price she had paid on numerous occasions but also because she realized that her relationship with the CSE would last for many years:

And you have to deal with those people all the time, unless they leave the job. We're going to have to work together for a long time. We have to make things better with the CSE. I'm the type of person where, if I know that someone feels uncomfortable near me or I'm uncomfortable with somebody else, I want to avoid thein. ... [But] I can't avoid that situation. It's something that I have to do. ${ }^{141}$

In effect, Juha Peterson recognized that she and the CSE chair were part of a "continuing relationship" 142 and that her normal approach to conflict-"avoidance"143 - could not be used under these circumstances. The EHA locked her into an ongoing relationship with her adversary, and she felt that she had to transform the ternis of that relationship from conflict to cooperation.

Ms. Peterson beheved that she had already conveyed to the CSE chair that she understood and would insist upon the legal rights of her children: "I wanted them to know I was aggressive enough that I was going to get what was fair for my child." ${ }^{144}$ Now it was time to tap the "other voice" as well, to attempt to understand the situation from the perspective of the CSE chair. Ms. Peterson read in the newspaper that the CSE chair would be appearing at the next school board meeting, "And I said to [my husband], let's go to this board meeting and see what it's tike and see what she has to say."145 Their experience at the board meeting changed their view of the CSE chair:

Well, what we found out was that she [the CSE chair] was telling the board what parents want, and they're [the board] telling her, "We'll think about it." And they're coming back and saying, "No, no, no, we can't do this." She's fighting for our rights and then she has to come and tell us, no. And then who do we take it out on? Herl ... It was like, I'm pulling her arm over here and they're pulling her arm over

140. Interview with "Julia and Thomas Peterson" (Oct. 21, 1987).

141. Interview with "Julia and Thomas Peterson" (Apr. 20, 1988).

142. For a discussion of "continuing relations," see text accompanying notes $2-4$.

143. For discussion of "avoidance" as a form of dispute processing, see Felstiner, Influences of Social Organization on Dispute Processing, 9 LAW \& Soc'Y REV. 63 (1974).

144. Interview with "Julia and Thomas Peterson" (Oct. 21, 1987).

145. Id. 
there, and she has to do her job. She's still not my favorite person, but I have a little more respect for her because of that. ${ }^{146}$

The Petersons' insights led to a profound change in their relationship with the CSE. When their second child came before the committee, the process was smooth and harmonious. By the time of my final interview with the Petersons, they were completely satisfied with the CSE and with the school their children attended. When asked to assess her committee, Julia Peterson said, "Great! Absolutely wonderful! I have no complaints. I wouldn't trade them for the world."147

This family's experience with the special education system was quite different from those discussed earher. The initial insistence upon the legal rights of their children, although it led to intense conflict, was an important first step to a more peaceful relationship. As Julia Peterson observed, "We just had to set some ground rules with them at the beginning." 148 Once the Petersons made it clear that they intended to protect the rights of their children, they then felt it was possible to view the matter from the perspective of the CSE chair without relinquishing services to which their children were entitled. Their relationship with the CSE was increasingly characterized by compassion and understanding but not capitulation. Through the efforts of these unusual parents, rights and relationships were developed in tandem, and they transformed a deteriorating situation into a highly successful educational experience for both children.

Joel Handler recently described the distinctive approach to special education used in Madison, Wisconsin. ${ }^{149}$ The Madison School District, according to Handler, encourages the use of parent advocates to advise, interpret, and argue on behalf of parents in their deahings with the interdisciplinary coinmittee. Altliough acknowledging that parents and committees are involved in a continuing relationship, the Madison School District also recognizes that on occasion parental protection of childrens' rights can and should lead to conflict. Handler observes that the District has in effect taken the position that such conflict should not be avoided or suppressed but encouraged: "[C]onflict is used to help communication." "150 If channelled along constructive paths, conflict can help both sides understand one another and tlius deepen and improve their ongoing relationship. With these considerations in mind, the Madison School

146. $I d$.

I47. Interview with "Julia and Thomas Peterson" (July 28, 1988).

148. Telephone interview with "Julia Peterson" (Oct. 2, 1987).

149. Handler, Dependent People, The State, and the Modern/Postmodern Search for the Dialogic Community, 35 UCLA L. REv. 999, 1010-12 (1988); J. HANDLER, supra note 2, at 84-118.

150. J. HANDLER, supra note 2, at 94. 
District embraced what many other districts fear and resent the mostthe active involvement of trained advocates to protect the rights of "handicapped" children. ${ }^{151}$

In theory, rights and relationships need not be mutually exclusive choices for parents in their dealings with CSEs. Rights analysis can serve as the framework for long-term relationships in which neither side dominates the other and both sides display the characteristics of Gilligan's "other voice"-connection, care, empathy, and responsiveness. In practice, however, the participants in the special education process lack a set of clearly defined images or models in which the two voices are combined effectively. My interviews revealed that CSE chairs, for example, tend to dislike the intrusion of advocates into the IEP process. They assume that the involvement of advocates constitutes an implicit accusation that the CSE has violated the law or, at the least, is not sufficiently concerned and sensitive to the child's interests. They believe that the presence of advocates tends to "legahze" the relationship between the parents and the committee and make meaningful communication more difficult. From their perspective, the vigorous pursuit of rights is inconsistent with creating and maintaining an effective relationship between parents and committee.

Many parents also believe that insistence upon their child's rights is incompatible with cultivating desired relationships between their family, the educational system, and the community. The world they envision for their child consists of a fabric of relationships that include their child's peers, teachers, therapists, aides, neighbors, and relatives. For themselves, they envision a mutually supportive, ongoing relationship with the CSE and the school district in general. In both of these imagined worlds, the assertion of rights is a discordant, alienating element that could attenuate or destroy relationships that might have value for other purposes. Although claims of rights violations can emphasize the child's equality and his or her right to integration, they can at the same time compound the problem of "difference" (because the rights in question were created only for children classified as "handicapped") and may be interpreted as an assault upon the school system and, indirectly, the very community the child seeks to join. ${ }^{52}$

151. Id. at 105-06.

152. Fear of retaliation against their child or themselves may also have dissuaded parents from a vigorous assertion of their rights against school district officials. Concern about the power of such officials was not often mentioned in the interviews, but it may have led some parents to submissive responses when they encountered unfair decisions. Parents who did bring in advocates to argue that rights had been violated, however, rarely experienced retaliation. 
This dilemma for parents resides at the core of the EHA. Although some parents and some school districts are able to discern ways in which the assertion of rights might be compatible with the forging of beneficial relationships with the world at large, the existing repertoire of cultural images and values mitigates against this perception. Thus, most parents in the study failed to take advantage of the procedural guarantees provided in the EHA to enforce substantive rights. To the extent that parents are not inclined to perceive their child's special education in terms of rights and entitlements, the legal protections established by the EHA are rendered meaningless.

\section{CONCLUSION}

The EHA created a forum, a community meeting place, for parents and professionals to come together and "bargain for reality."153 These meetings generate images, definitions, and programs that determine the status and fate of American children with disabilities. Unlike other arenas of interaction in the community, however, the CSEs lack a tradition that defines the roles of the participants. Brought together by a mandate to meet at least once a year to devise an "appropriate" education for each child, ${ }^{154}$ the participants circle each other warily. To express their differing viewpoints, they search among the various ideas and concepts by which children with disabilities are understood in our culture, no matter how ill-suited or contradictory those ideas might be. The parents hold tenuously to the due process protections of the EHA, although they generally have neither the understanding nor the inclination to invoke them. The school district personnel are more confident, usually wielding superior political power-the capacity to define the problem, to dictate the language used to discuss the child, to intimidate, to retaliate, or to ignore.

In this forum, law and culture merge. Culture is a context for human interaction, a "web of significance" that humans themselves spin. ${ }^{155}$ Congressional pronouncements on the rights of children with disabilities form a part of that socially constructed web, as do popular images of persons with disabilities, of professionals and professionalism, of scientific interpretations of "handicap," of education, and of rights themselves. School district committee meetings represent occasions on which the meanings of such concepts can be invoked and played outtheir implications and internal contradictions explored and tested. I

153. The phrase is borrowed from L. Rosen, BARGAINING For REALITY (1984) (discussing how social relationships in Moroccan culture acquire meaning through a continuing process of bargaining and negotiation).

154. See supra note 56.

155. C. GEERTZ, supra note 5 , at 5. 
have described the "web of significance" associated with certain key concepts in the special education system. In my discussion of the concept of "handicap" and of professional and parental roles, I have suggested a tension between conceptualizations that emphasized boundaries or dichotomies on the one hand and commonalities or continua on the other. ${ }^{156}$ The emphasis on boundaries or dichotomies derives from a perception of disabilities as fundamental departures from "normal" function and appearance. That view is further linked to a perception of professionals as uniquely qualified to understand and evaluate children with disabilities in scientific terms that are inaccessible to most laypeople. An emphasis on commonalities or continua, on the other hand, is associated with the perception of disabilities as a normal part of the broad range of human experience and personality. It also is connected with a social construction of knowledge that accords validity to both "scientific" and lay perspectives.

The tension between these two types of conceptualization explains why the EHA has operated in unexpected ways in local school districts. Conceptualizations that emphasize boundaries and dichotomies tend, by their very nature, to reproduce the segregation of children with disabilities and the disempowerment of their parents in the CSE process. Conceptualizations that emphasize commonalities and continua tend to foster integration for the children and greater participation and authority for their parents.

With respect to the issue of rights and relationships, however, the situation becomes more complex. Rights analysis is contradictory in its implications for children with disabilities. With its emphasis on universalism and on the entitlements guaranteed by the state to each individual, it is closely related to the perspectives characterized by commonalities and continua. Children with disabilities are entitled to the same privileges-including the right to a public education-as "normal" children. Yet, the methodology of rights analysis also emphasizes boundaries and fundamental distinctions between children with disabilities and their peers. To qualify a child as the possessor of a right to an "appropriate education" under the EHA, one must first prove the existence of a "handicap" and thereby differentiate the child in question from "normal" children. Only by perpetuating this dichotomized perspective can rights analysis operate. If children with disabilities are not distinguished

156. See Katz, Studies in Boundary Theory: Three Essays in Adjudication and Politics, 28 BUFFALO L. REV. 383 (1979) (distinguishing between two types of boundaries operative in the processes of reason and perception: "Vacuum Boundaries," which completely separate opposing categories and cannot be blurred or breached; and "Live Boundaries," which permit movement and compromise between categories). 
at the outset, then the universalism of rights analysis could not justify their entitlement to a "special" education that is not afforded equally to every other child.

As an alternative to rights analysis, an emphasis on the relationships linking children and their parents to others in the community is more consistent with the "commonahities and continua" perspectives that tend to produce integration rather than segregation. Yet when relatively disempowered parents deal with school district committees on the basis of a "relationships" perspective, they frequently forego the assertion of claims that could move their children out of segregated settings and inadequate programs. Unless all the participants in the CSE process commit to a relationships perspective, and unless power is shared by all, then this perspective tends to produce more, rather than less, segregation.

In the world in which these parents and children live, the rights analysis at the core of the EHA provides an indispensable instrument for integration and empowerment of children with disabilities and their parents. Yet, in their reluctance to adopt the rights perspective, parents correctly sense that it contains a hidden but highly destructive set of miplications. Although it might liberate their children from isolated and inadequate educational programs, rights analysis simultaneously can remforce an already prevalent understanding that children with disabilities are separated from "normal" children by clear and unmistakable boundaries. The assertion of rights under the EHA could thus reproduce, in the long run, the very distinctions it sets out to obliterate and could relegate children with disabilities to a life of "otherness" from which neither law nor culture can free them. 